\title{
Oxygen free radicals and calcium homeostasis in the heart
}

\author{
Masanori Kaneko, Yuji Matsumoto, Hideharu Hayashi*, \\ Akira Kobayashi and Noboru Yamazaki
}

The Third Department of Internal Medicine, and *Photon Medical Research Center, Hamamatsu University School of Medicine, Hamamatsu 431-31, Japan

\begin{abstract}
Many experiments have been done to clarify the effects of oxygen free radicals on $\mathrm{Ca}^{2+}$ homeostasis in the hearts. A burst of oxygen free radicals occurs immediately after reperfusion, but we have to be reminded that the exact levels of oxygen free radicals in the hearts are yet unknown in both physiological and pathophysiological conditions. Therefore, we should give careful consideration to this point when we perform the experiments and analyze the results.

It is, however, evident that $\mathrm{Ca}^{2+}$ overload occurs when the hearts are exposed to an excess amount of oxygen free radicals. Though ATP-independent $\mathrm{Ca}^{2+}$ binding is increased, $\mathrm{Ca}^{2+}$ influx through $\mathrm{Ca}^{2+}$ channel does not increase in the presence of oxygen free radicals. Another possible pathway through which $\mathrm{Ca}^{2+}$ can enter the myocytes is $\mathrm{Na}^{+}-\mathrm{Ca}^{2+}$ exchanger. Although, the activities of $\mathrm{Na}^{+}-\mathrm{K}^{+}$ATPase and $\mathrm{Na}^{+}-\mathrm{H}^{+}$exchange are inhibited by oxygen free radicals, it is not known whether intracellular $\mathrm{Na}^{+}$level increases under oxidative stress or not. The question has to be solved for the understanding of the importance of $\mathrm{Na}^{+}-$ $\mathrm{Ca}^{2+}$ exchange in $\mathrm{Ca}^{2+}$ influx process from extracellular space. Another question is ' which way does $\mathrm{Na}^{+}-\mathrm{Ca}^{2+}$ exchange work under oxidative stress? Net influx or efflux of $\mathrm{Ca}^{2+}$ ?' Membrane permeability for $\mathrm{Ca}^{2+}$ may be maintained in a relatively early phase of free radical injury. Since sarcolemmal $\mathrm{Ca}^{2+}$-pump ATPase activity is depressed by oxygen free radicals, $\mathrm{Ca}^{2+}$ extrusion from cytosol to extracellular space is considered to be reduced. It has also been shown that oxygen free radicals promote $\mathrm{Ca}^{2+}$ release from sarcoplasmic reticulum and inhibit $\mathrm{Ca}^{2+}$ sequestration to sarcoplasmic reticulum. Thus, these changes in $\mathrm{Ca}^{2+}$ handling systems could cause the $\mathrm{Ca}^{2+}$ overload due to oxygen free radicals. (Mol Cell Biochem 139: 91-100, 1994)
\end{abstract}

Key words: sarcolemma, myofibrils, $\mathrm{Na}^{+} / \mathrm{Ca}^{2+}$ exchange, sarcoplasmic reticulum, cardiac contraction, $\mathrm{Ca}^{2+}$ pump

\section{Introduction}

During the last decade, the role of oxygen free radicals in myocardial ischemia-reperfusion injury has been studied extensively. Although, the most important pathways through which free radicals may be formed during ischemiareperfusion have not been defined precisely, several lines of evidence have shown that a burst of oxygen free radicals occurs immediately after reperfusion [1-4]. It has been also reported that oxygen free radicals have the ability to cause the dysfunction of the heart, and that various types of free radical scavengers have protective effects on ischemiareperfusion injury [5-10]. These data suggest that oxygen free radicals is one of the crucial factors in ischemiareperfusion injury. It is also well accepted that intracellular $\mathrm{Ca}^{2+}$ overload plays an important role in ischemiareperfusion injury [11-16]. $\mathrm{Ca}^{2+}$ overload could have serious consequences for the myocyte through activation of a variety of enzymes such as proteases, lipases, and phospholipases [17] or ATPase [11, 12]. In addition, $\mathrm{Ca}^{2+}$ is actively accumulated and precipitated with phosphate in the matrix space of mitochondria [18]. This process is associ- 
ated with inhibition of ATP synthesis [18] via mitochondrial oxidative phosphorylation and the ATP synthetase. Therefore, clarification of the relationship between oxygen free radicals and $\mathrm{Ca}^{2+}$ homeostasis is necessary to understand the detail mechanisms for cellular injury in myocardial ischemia-reperfusion. The purpose of the present treatise is to discuss on this subject. In the first section, we discuss on the effects of oxygen free radicals on $\mathrm{Ca}^{2+}$ handling systems in the heart. In the next section, effects of oxygen free radicals on intracellular $\mathrm{Ca}^{2+}$ concentration are discussed.

\section{Effects of oxygen free radicals on $\mathrm{Ca}^{2+}$ handling systems in the heart}

Cytosolic $\mathrm{Ca}^{2+}$ overload can occur either because of increased $\mathrm{Ca}^{2+}$ influx from extracellular space to cytosol or because of insufficient $\mathrm{Ca}^{2+}$ extrusion from cytosol. Cytosolic $\mathrm{Ca}^{2+}$ concentration is also affected by subcellular $\mathrm{Ca}^{2+}$ store sites such as sarcoplasmic reticulum. Therefore, the following discussion is divided into three parts. The first part is the effects of oxygen free radicals on $\mathrm{Ca}^{2+}$ influx from the extracellular space to intracellular space. These processes include ATPindependent $\mathrm{Ca}^{2+}$ binding, $\mathrm{Ca}^{2+}$ channels, adrenergic receptors, $\mathrm{Na}^{+}-\mathrm{Ca}^{2+}$ exchange, $\mathrm{Na}^{+}-\mathrm{K}^{+}$ATPase, $\mathrm{Na}^{+}-\mathrm{H}^{+}$exchange, and permeability of cardiac sarcolemmal membranes. The second part is the effects of oxygen free radicals on $\mathrm{Ca}^{2+}$ extrusion systems, which include $\mathrm{Na}^{+}-\mathrm{Ca}^{2+}$ exchange and $\mathrm{Ca}^{2+}$ pump ATPase of sarcolemmal membranes. The final part is the effects of oxygen free radicals on $\mathrm{Ca}^{2+}$ translocating processes of sarcoplasmic reticulum.

\section{I: $\mathrm{Ca}^{2+}$ influx from extracellular space to intracellular space}

It is well accepted that excitation-contraction coupling in mammalian heart include two critical $\mathrm{Ca}^{2+}$ components. One component of $\mathrm{Ca}^{2+}$ comes directly from influx across the sarcolemmal membrane, and another component of $\mathrm{Ca}^{2+}$ is derived from the sarcoplasmic reticulum via the process of $\mathrm{Ca}^{2+}$-induced $\mathrm{Ca}^{2+}$-release $[19,20]$. The $\mathrm{Ca}^{2+}$-channel and the $\mathrm{Na}^{+}-\mathrm{Ca}^{2+}$ exchanger are recognized as responsible for this transsarcolemmal influx of $\mathrm{Ca}^{2+}[21]$, though $\mathrm{Na}^{+}-\mathrm{Ca}^{2+}$ exchanger also operates to produce a net efflux of $\mathrm{Ca}^{2+}(22$, 23].

\section{ATP-independent $\mathrm{Ca}^{2+}$-binding}

The sources of $\mathrm{Ca}^{2+}$ that enters the cell across the sarcolemma are considered to be the extracellular space and $\mathrm{Ca}^{2+}$ binding sites within the sarcolemmal membranes [24-26]. Langer et al. [24-26] reported that membrane bound $\mathrm{Ca}^{2+}$ in cardiac cell is a superficial store of $\mathrm{Ca}^{2+}$, which becomes available for entry upon excitation of the myocardium. Kinetic studies of $\mathrm{Ca}^{2+}$ binding with sarcolemmal membrane in the absence of ATP have revealed the presence of both low-affinity, high-capacity $\mathrm{Ca}^{2+}$-binding site and highaffinity, low-capacity $\mathrm{Ca}^{2+}$-binding site [26]. The amount of $\mathrm{Ca}^{2+}$ that enters the cell is a major determinant of the concentration of $\mathrm{Ca}^{2+}$ at the myofilaments during systole, and is a major determinant of the level of contactile force as a result [26]. In fact, ATP-independent $\mathrm{Ca}^{2+}$-binding in heart sarcolemma has been shown to exhibit linear relationship with the contactile force development in the normal myocardium [24-28].

We have examined the effects of oxygen free radicals on this ATP-independent $\mathrm{Ca}^{2+}$-binding activity in rat heart sarcolemmal membrane [29]. In the presence of xanthine plus xanthine oxidase or hydrogen peroxide, both low- and highaffinity $\mathrm{Ca}^{2+}$-binding activities were increased after $5 \mathrm{~min}$ incubation. Philipson et al. [30] showed that more than $80 \%$ of $\mathrm{Ca}^{2+}$ was bound to membrane phospholipids at physiological level of extracellular $\mathrm{Ca}^{2+}$. Since oxygen free radicals are known to promote the peroxidation of membrane phospholipids [31], it is likely that the changes in ATP-independent $\mathrm{Ca}^{2+}$-binding by oxygen free radicals are due to alterations in the phospholipid composition of the membrane.

\section{2. $\mathrm{Ca}^{2+}$ channels}

$\mathrm{Ca}^{2+}$ channels are intrinsic membrane glycoproteins that participate in the regulation of transmembrane ion flow and cellular function in the heart [32-34]. $\mathrm{Ca}^{2+}$ channels open in response to changes in membrane potential and allow $\mathrm{Ca}^{2+}$ to enter cells. This inward movement of $\mathrm{Ca}^{2+}$ depolarizes the heart cell membrane and contributes to the plateau phase of the action potential, pacemaker activity, and impulse conduction [35-37]. In addition, the influx of $\mathrm{Ca}^{2+}$ causes a transient rise in intracellular $\mathrm{Ca}^{2+}$ concentration, which in turn can initiate the cardiac contraction [38-41].

We have examined the effects of oxygen free radicals on the binding of $\mathrm{Ca}^{2+}$ channel antagonists by employing $\left[{ }^{3} \mathrm{H}\right]$ nitrendipine as a ligand. Isolated rat heart membranes were incubated with various types of oxygen free radicals-generating system, and the assay of the $\left[{ }^{3} \mathrm{H}\right]$-nitrendipine binding activity revealed that the maximal number of binding sites (Bmax) was reduced in a time-dependent manner without any significant changes in the binding constant (Kd); a significant reduction of $B \max$ was seen after incubating the membranes with free radical-generating systems for a 10 min-period [42]. These results indicate that oxygen free radicals may reduce the number of voltage-dependent $\mathrm{Ca}^{2+}$ channels and this change may contribute towards decreasing the voltage-dependent $\mathrm{Ca}^{2+}$ influx of the cardiac cells.

In electrophysiological studies, Burrington et al. [43], 
Hayashi et al. [44], Beresewicz et al. [45], and Jabr and Cole [46] have reported that oxygen free radicals produced an initial prolongation of action potential duration of rat and guinea pig ventricular myocytes, and that the prolongation of action potential duration was followed by a shortening of duration. Pallandi et al. [47] reported that xanthine oxidase-generated free radicals reduced the amplitude after 20 to $30 \mathrm{~min}$ exposure but did not affect the duration of the action potential in guinea pig ventricular strips. Cerbai et $a l$. [48] reported a prolongation of action potential duration by dihydroxyfumarate in guinea pig ventricular myocytes. On the other hand, Nakaya et al. [49] reported that organic hydroperoxides produced decreases in both the amplitude and the duration of action potential of guinea pig papillary muscles and canine Purkinje fibers, and that it took $10 \mathrm{~min}$ of superfusion with hydrogen peroxides for the changes in resting potential and action potential to occur. It was, therefore, shown that the effects of free radicals on action potential duration were variable according to duration of the perfusion and to the species of free radicals. On the other hand, action potential duration can be influenced not only by $\mathrm{Ca}^{2+}$ current but by $\mathrm{K}^{+}$current.

Goldhaber et al. [50] observed that $1 \mathrm{mM} \mathrm{H}_{2} \mathrm{O}_{2}$ or $1 \mathrm{mM}$ xanthine plus $0.01 \mathrm{U} / \mathrm{ml}$ xanthine oxidase caused a rapid decrease in the amplitude of the $\mathrm{Ca}^{2+}$ current in patchclamped guinea pig single ventricular myocytes. Cerbai et al. [48] also reported that $\mathrm{Ca}^{2+}$ current was rapidly reduced by the superfusion of guinea pig ventricular myocytes with $5 \mathrm{mM}$ dihydroxyfumarate (DHF). They observed that after 2 min of exposure to DHF, the peak $\mathrm{Ca}^{2+}$ current was decreased about $70 \%$ of its initial value, without any appreciable modification of its kinetics. Tarr et al. [51] showed that rose bengal-generated oxygen free radicals suppressed $\mathrm{Ca}^{2+}$ currents in single frog atrial cells. Nakaya et al. [52] also reported that 10 to $30 \mu \mathrm{M}$ cumene hydroperoxide decreased the $\mathrm{Ca}^{2+}$ currents of guinea pig ventricular cells.

These results indicate that $\mathrm{Ca}^{2+}$ influx through the voltage-dependent $\mathrm{Ca}^{2+}$ channels could not be the cause of $\mathrm{Ca}^{2+}$ overload during the exposure to oxygen free radical-generating systems.

\section{Adrenergic receptors}

The $\beta$-adrenergic receptor-stimulatory guanine nucleotidebinding protein (Gs) - adenylate cyclase system is a plasma membrane-bound protein assembly consisting of three major components $[53,54]$. The heterotrimetric guanine nucleotide-binding regulatory proteins couple with extracellular receptors and cause stimulation (Gs) or inhibition (Gi) of the effector enzyme adenylate cyclase, which is the primary regulator of the intracellular concentration of the second messenger cyclic AMP (cAMP) [53-55]. In the heart, $\alpha$ subunit of the $\mathrm{Gs}(\mathrm{Gs} \alpha)$ plays a central role in the regulation of cardiac function [56] as in addition to transducing $\beta$-adrenergic receptor-mediated activation of adenylate cyclase. The Gs $\alpha$ regulates the phosphorylation of $\mathrm{Ca}^{2+}$ channels indirectly by cAMP-dependent protein kinase [57], and it activates voltage-dependent $\mathrm{Ca}^{2+}$ channels by a more direct interaction [58]. Cyclic AMP-dependent protein kinases can also promote the phosphorylation of other regulatory proteins such as phospholamban in the sarcoplasmic reticulum and troponin I in myofibrils [59]. Therefore, the changes in $\beta$-receptor - Gs - adenylate cyclase system can affect $\mathrm{Ca}^{2+}$ homeostasis in the heart.

Haenen et al. [60] reported that although a low concentration $\left(1 \times 10^{-7}-1 \times 10^{-3} \mathrm{M}\right)$ of hydrogen peroxide increased $\mathrm{Bmax}$ for $\left[{ }^{125} \mathrm{I}\right]$-iodocyanopindrol binding, while a high concentration $\left(1 \times 10^{-1} \mathrm{M}\right)$ of hydrogen peroxide decreased Bmax. We observed that both Bmax and $\mathrm{Kd}$ for $\left[{ }^{3} \mathrm{H}\right]-$ dihydroalprenol (DHA) binding were increased by xanthine plus xanthine oxidase after 10 min of incubation in rat heart. One $\mathrm{mM}$ of hydrogen peroxide increased the $\mathrm{Kd}$ value whereas Bmax was unaffected [61]. When a hydrophilic ligand, $\left[{ }^{3} \mathrm{H}\right]$-CGP-12177, was used for the $\beta$-adrenergic receptor assay, an increase in $\mathrm{Kd}$ value without any significant changes in Bmax was seen on treating the membrane with xanthine plus xanthine oxidase [61]. We also examined the direct effects of hydrogen peroxide on Gs activity, and observed that hydrogen peroxide ( 0.1 to $10 \mathrm{mM})$ did not cause any significant effects on both Gs activity and the coupling in the $\beta$-adrenergic receptor - Gs - adenylate cyclase system in rat cardiac membranes [62]. Will-Shahab et al. [63], Shimke et al. [64], and we [62] showed that adenylate cyclase activity was depressed by oxygen free radicals. Furthermore, in the presence of oxygen free radical-generating systems, cAMP productions after stimulation with GTP, GTP $+(1)$-isoproterenol, Gpp $(\mathrm{NH}) \mathrm{p}$, and $\mathrm{Gpp}(\mathrm{NH}) \mathrm{p}+(1)$ isoproterenol were reduced [62]. Therefore, it seems that the changes in $\beta$-adrenergic receptor systems under oxidative stress may not lead to $\mathrm{Ca}^{2+}$ overload in the heart.

\section{4. $\mathrm{Na}^{+}-\mathrm{Ca}^{2+}$ exchange, $\mathrm{Na}^{+}-\mathrm{K}^{+}$ATPase, and $\mathrm{Na}^{+}-\mathrm{H}^{+}$ exchange}

The $\mathrm{Na}^{+}-\mathrm{Ca}^{2+}$ exchange system can move $\mathrm{Ca}^{2+}$ either into or out of the cytosol, across the plasma membrane, in exchange for $\mathrm{Na}^{+}$[65]. The net direction of $\mathrm{Ca}^{2+}$ movement mediated by the exchanger depends on the $\mathrm{Na}^{+}$and/or the $\mathrm{Ca}^{2+}$ electrochemical gradient, the stoichiometry, and the membrane potentials during the action potential [65]. Since the reversal potential for the exchange $\left(\mathrm{E}_{\mathrm{Na} / \mathrm{Ca}}\right)$ is slightly positive to the resting membrane potential during diastole, there is a small net outward movement of $\mathrm{Ca}^{2+}$, mediated by the exchange that operates in parallel with the $\mathrm{Ca}^{2+}$-pump ATPase to maintain the low resting $\mathrm{Ca}^{2+}$ level in the cytosol. During the upstroke of the action potential, the driving force becomes positive, and this tends to drive $\mathrm{Ca}^{2+}$ into the cells in exchange for $\mathrm{Na}^{+}$. The net $\mathrm{Ca}^{2+}$ entry mediated by the 
exchange may continue through the plateau phase of the action potential. Then as the cell repolarizes because of the opening of $\mathrm{K}^{+}$-selective channels, the driving force becomes negative; this results in net efflux of $\mathrm{Ca}^{2+}$ mediated by the exchange operating in the $\mathrm{Ca}^{2+}$ efflux mode [66].

$\mathrm{Na}^{+}-\mathrm{Ca}^{2+}$ exchange is also affected by the changes in the activities of $\mathrm{Na}^{+}-\mathrm{K}^{+}$ATPase and $\mathrm{Na}^{+}-\mathrm{H}^{+}$exchange. Inhibition of the $\mathrm{Na}^{+}-\mathrm{K}^{+}$ATPase produces a rise in intracellular level of $\mathrm{Na}^{+}[67,68]$. An elevation of the intracellular $\mathrm{Na}^{+}$ will lead to the rise in intracellular $\mathrm{Ca}^{2+}$ either by a decreased $\mathrm{Ca}^{2+}$ efflux or by an increased $\mathrm{Ca}^{2+}$ influx via $\mathrm{Na}^{+}-\mathrm{Ca}^{2+} \mathrm{ex}-$ change [23]. The inhibition of the $\mathrm{Na}^{+}-\mathrm{K}^{+}$ATPase also results in an intracellular acidification that is thought to be a consequence of a rise in intracellular $\mathrm{Ca}^{2+}$ produced via $\mathrm{Na}^{+}-\mathrm{Ca}^{2+}$ exchange [69-71]. Furthermore, measurements of intracellular $\mathrm{Na}^{+}$have shown that inhibitors of $\mathrm{Na}^{+}-\mathrm{H}^{+}$exchange decrease the rise in intracellular $\mathrm{Na}^{+}$which was produced by ouabain [70, 72-74]. These results suggest that even in the presence of ouabain, $\mathrm{Na}^{+}-\mathrm{H}^{+}$exchange is producing a net $\mathrm{Na}^{+}$influx which increases intracellular $\mathrm{Ca}^{2+}$ via $\mathrm{Na}^{+}-\mathrm{Ca}^{2+}$ exchange $[23,70]$. Thus, these three ion transporting systems can affect each other, and play important roles in $\mathrm{Ca}^{2+}$ handling in cardiac cells.

Kramer et al. [75] demonstrated that $\mathrm{Na}^{+}-\mathrm{K}^{+}$ATPase activity was reduced by oxygen free radical-generating system (dihydroxyfumarate and $\mathrm{Fe}^{3+}$ - $\mathrm{ADP}$ ) in canine cardiac sarcolemmal membranes. Kukreja et al. [78] also showed that the inhibition of $\mathrm{Na}^{+}-\mathrm{K}^{+}$ATPase activity was seen in the presence of $\mathrm{H}_{2} \mathrm{O}_{2}, \mathrm{H}_{2} \mathrm{O}_{2}$ plus $\mathrm{Fe}^{2+}$, $\mathrm{HOCl}, \mathrm{NH}_{2} \mathrm{Cl}$, or PMA-stimulated human neutrophils whereas the enzyme activity was not changed by xanthine plus xanthine oxidase in dog heart sarcolemmal vesicles. Bhatnagar et al. [77] observed that superfusion of frog ventricular single cells with tert-butyl hydroperoxide(t-BHP) increased intracellular $\mathrm{Na}^{+}$which could result from a decrease in $\mathrm{Na}^{+}$efflux via $\mathrm{Na}^{+}-\mathrm{K}^{+}$pump. On the other hand, Xie et al. [102] reported that both $\mathrm{Na}^{+}-\mathrm{K}^{+}$ATPase and $\mathrm{Na}^{+}-\mathrm{H}^{+}$exchange activities were reduced by xanthine plus xanthine oxidase and that $\mathrm{Na}^{+}-\mathrm{H}^{+}$ exchange was more sensitive to oxidative stress than that of $\mathrm{Na}^{+}-\mathrm{K}^{+}$ATPase. Furthermore, they observed that ${ }^{45} \mathrm{Ca}^{2+}$ uptake by myocytes was increased in the presence of ouabain, however, ${ }^{45} \mathrm{Ca}^{2+}$ uptake was decreased by xanthine plus xanthine oxidase. Their data suggest that intracellular $\mathrm{Na}^{+}$may not increase to the level which can promote $\mathrm{Ca}^{2+}$ influx via $\mathrm{Na}^{+}-\mathrm{Ca}^{2+}$ exchange under oxidative stress, since $\mathrm{Na}^{+}-\mathrm{H}^{+}$exchange is inhibited by free radicals as well as $\mathrm{Na}^{+}-\mathrm{K}^{+}$ATPase.

These data support that heart sarcolemmal activities of $\mathrm{Na}^{+}-\mathrm{K}^{+}$ATPase and $\mathrm{Na}^{+}-\mathrm{H}^{+}$exchange are reduced by oxygen free radicals. Kim et al. [76] reported that ischemiareperfusion of isolated guinea pig heart reduced $\mathrm{Na}^{+}-\mathrm{K}^{+}$ ATPase activity and specific $\left[{ }^{3} \mathrm{H}\right]$-ouabain binding to the enzyme; these effects of ischemia-reperfusion were prevented to various degrees by oxygen free radical scavengers, such as superoxide dismutase, catalase, dimethylsulfoxide, histidine, or vitamin E, or by the xanthine oxidase inhibitor, allopurinol. It was, therefore, suggested that an increase in free radicals during ischemia-reperfusion was implicated in reduced $\mathrm{Na}^{+}-\mathrm{K}^{+}$ATPase activity. The direct effects of oxygen free radicals on $\mathrm{Na}^{+}-\mathrm{Ca}^{2+}$ exchange is discussed in the next part of this chapter.

\section{Membrane permeability, membrane fluidity, and phosphatidylethanolamine $N$-methylation}

One of the main targets of oxygen free radicals appears to be the polyunsaturated fatty acids of the membrane phospholipids [31]. Lipid peroxidation can be initiated by the interaction of a reactive oxidant with a fatty acid to form a lipid radical, which then can react rapidly with $\mathrm{O}_{2}$ to form the corresponding peroxy radical. This peroxy radical can then attack a neighboring fatty acid to form the hydroperoxide and a new alkyl radical. This reaction will propagate until two radical species unite in a chain-terminating reaction to form a non-radical product, or until a radical reacts with an agent, such as $\alpha$-tocopherol, that forms stable radicalls [31]. Such chain reactions can result in substantial membrane damage and can change ion permeability and fluidity of membranes [78-81].

Ytrehus et al. [82] observed the fragmentation of sarcolemma with subsequent leakage of cell organelles into the interstitium after $10 \mathrm{~min}$ Langendorff perfusion of rat heart with $0.96 \mathrm{mM}$ hypoxanthine plus $0.025 \mathrm{U} / \mathrm{ml}$ xanthine oxidase. Levedev et al. [83] reported that $\mathrm{Ca}^{2+}$ permeability of bilayer lipid membranes consisting of phosphatidylcholines in a mixture with cholesterol was increased when the membranes were formed from oxidizing lipids or when initiators of lipid peroxidation, ascorbate and iron ions, were added to both sides of the membrane. On the other hand, Bhatnagar et al. [77] reported that plasma membrane permeability for $\mathrm{Ca}^{2+}$ remained intact even after 30 min exposure to t-BHP in single cells isolated from frog ventricle. Hata et al. [84] also showed that rat heart sarcolemmal permeability for $\mathrm{Ca}^{2+}$ and $\mathrm{Na}^{+}$was not changed upon treatment with $2 \mathrm{mM}$ xanthine plus $0.03 \mathrm{U} / \mathrm{ml}$ xanthine oxidase, $0.5 \mathrm{mM} \mathrm{H}_{2} \mathrm{O}_{2}$, or $0.01 \mathrm{mM} \mathrm{H}_{2} \mathrm{O}_{2}$ plus $0.01 \mathrm{mM} \mathrm{Fe}^{2+}$ for 30 min. Thus, it seems likely that sarcolemmal membrane permeability for $\mathrm{Ca}^{2+}$ may be maintained in a early phase of he injury, while it is increased in a final stage of membrane damage caused by oxygen free radicals. It may be difficult for the cells to maintain the cell functions in the situation in which cell membrane permeability for $\mathrm{Ca}^{2+}$ is increased.

Lipid peroxidation of membrane phospholipids also results in the changes in membrane fluidity. Many researchers reported that membrane fluidities were decreased by the peroxidation of phospholipid vesicles, erythrocytes, microsomes, and mitochondrial membranes [85-91], whereas Grzelinska et al. [92] showed increased membrane 
fluidity following peroxidation of erythrocytes membrane. We [93] observed that heart sarcolemmal, sarcoplasic reticular, and mitochondrial membrane fluidities were decreased by $2 \mathrm{mM}$ xanthine plus $0.03 \mathrm{U} / \mathrm{ml}$ xanthine oxidase during 5 to $30 \mathrm{~min}$ of incubation. However, these membrane fluidities were increased after $60 \mathrm{~min}$ of incubation. The decrease in the membrane fluidity can be due to lipid peroxidation of membrane phospholipids by oxygen free radicals. The later increase in the fluidity is considered to reflect the disruption of the membranes, membrane permeability for $\mathrm{Ca}^{2+}$ may increase in such condition.

The intramembranal rearrangement of the two major membrane phospholipids, phosphatidylethanolamine (PE) and phosphatidylcholine (PC), can be regulated by phospholipid N-methylation [94]. Phospholipid N-methylation has been considered to have important implication for cell membrane properties such as membrane fluidity [95], membrane-bound enzyme activities [96-99], and $\beta$-adrenergic receptors [100]. The PE N-methylation in rat heart sarcolemmal and sarcoplasmic reticular membranes was reduced by oxygen free radicals [101]. Thus, oxygen free radicals can modify the membrane integrity by altering the PE Nmethylation process as well as lipid peroxidation.

\section{II. $\mathrm{Ca}^{2+}$ extrusion from intracellular space to extracellu- lar space}

To maintain the levels of $\mathrm{Ca}^{2+}$ ion in cytosol and subcellular $\mathrm{Ca}^{2+}$ store sites, $\mathrm{Ca}^{2+}$ which entered the cells from the extracellular space during the action potential, has to be pumped out from the cytosol to extracellular space. It is believed that heart sarcolemma contains two important mechanisms for extruding $\mathrm{Ca}^{2+} ; \mathrm{Na}^{+}-\mathrm{Ca}^{2+}$ exchange and $\mathrm{Ca}^{2+}$-pump ATPase [103-105].

\section{1. $\mathrm{Na}^{+}-\mathrm{Ca}^{2+}$ exchange}

In the heart, $\mathrm{Na}^{+}-\mathrm{Ca}^{2+}$ exchange is thought to function primarily as a mechanism for pumping $\mathrm{Ca}^{2+}$ out of the cell, it is, however, possible that $\mathrm{Na}^{+}-\mathrm{Ca}^{2+}$ exchanger can also promote the net entry of $\mathrm{Ca}^{2+}$ into the cell under certain circumstances such as membrane depolarization as described in the previous part. The effects of oxygen free radicals on $\mathrm{Na}^{+}-\mathrm{Ca}^{2+}$ exchange is controversial. Reeves et al. [106] reported that $\mathrm{Na}^{+}-\mathrm{Ca}^{2+}$ exchange system in sarcolemmal vesicles of bovine ventricular tissue was stimulated by both oxidizing and reducing agents. $\mathrm{Na}^{+}-\mathrm{Ca}^{2+}$ exchange activity was stimulated by preincubating the vesicles with $1 \mu \mathrm{M} \mathrm{FeSo}_{4}$ plus $1 \mathrm{mM}$ dithiothreitol (DTT) which is known to generate superoxide anion radical, $\mathrm{H}_{2} \mathrm{O}_{2}$, and hydroxyl radical, xanthine plus xanthine oxidase, $\mathrm{Fe}^{2+}$ plus $\mathrm{H}_{2} \mathrm{O}_{2}$, or GSH plus GSSG [106]. However, the exchange activity was not affected by $\mathrm{H}_{2} \mathrm{O}_{2}, \mathrm{GSH}$, or GSSG, alone [106]. Based on these data, they considered that the redox agents may activate exchange activity by promoting thiol-disulfide interchange in the carrier protein [106]. Shi et al. [107] reported that exposure of bovine heart sarcolemmal vesicles to $50 \mu \mathrm{M} \mathrm{FeSo}_{4}$ plus $1 \mathrm{mM}$ DTT for 1 to 40 min stimulated $\mathrm{Na}^{+}-\mathrm{Ca}^{2+}$ exchange and decreased the apparent $\mathrm{Km}$ for $\mathrm{Ca}^{2+}$ of $\mathrm{Na}^{+}$-dependent $\mathrm{Ca}^{2+}$ uptake. Conversley, others $[102,108-110]$ reported that $\mathrm{Na}^{+}-\mathrm{Ca}^{2+}$ exchange activity was reduced by oxygen free radicals. Kutryk and Pierce [108] showed that $\mathrm{Na}^{+}-\mathrm{Ca}^{2+}$ exchange activity in canine heart sarcolemmal vesicles was depressed by $50 \mu \mathrm{mol} / \mathrm{mg}$ of protein $\mathrm{H}_{2} \mathrm{O}_{2}$ or by cholesterol oxidase. Xie et al. [102] also observed that $\mathrm{Na}^{+}-\mathrm{Ca}^{2+}$ exchange activity in rat myocytes was decreased by $1 \mathrm{mM}$ xanthine plus $0.08 \mathrm{U} / \mathrm{mol}$ xanthine oxidase after 30 min of incubation. Furthermore, Hata et al. [84] showed that various types of oxygen free radical-generating systems inhibited the $\mathrm{Na}^{+}-\mathrm{Ca}^{2+}$ exchange activity in sarcolemmal membrane vesicles isolated from rat, bovine, canine, and porcine hearts. Bersohn et al. [112], Daly et al. [109], Meon et al. [110], and Dixon et al. [111, 113] reported that heart sarcolemmal $\mathrm{Na}^{+}-\mathrm{Ca}^{2+}$ exchange activity was depressed in hearts subjected to ischemia-reperfusion or hypoxiareoxygenation, and that the reduced activity of $\mathrm{Na}^{+}-\mathrm{Ca}^{2+}$ exchange in ischemia-reperfused hearts was prevented by the addition of free radical scavengers to the perfusate [113].

\section{2. $\mathrm{Ca}^{2+}$-pump ATPase of sarcolemmal membrane}

We $[114,115]$ observed the effects of oxygen free radicals on $\mathrm{Ca}^{2+}$-pump ATPase activity and the mechanism for the effects. The $\mathrm{Ca}^{2+}$ ATPase activity and ATP-dependent $\mathrm{Ca}^{2+}$ accumulation in rat heart sarcolemmal inside-out vesicles were reduced by xanthine plus xanthine oxidase, $\mathrm{H}_{2} \mathrm{O}_{2}$, or $\mathrm{H}_{2} \mathrm{O}_{2}$ plus $\mathrm{Fe}^{2+}$ both in a dose- and a time-dependent manner; a significant inhibition of the activity was seen after $1 \mathrm{~min}$ of incubation. Since $\mathrm{Ca}^{2+}$-pump ATPase in cardiac sarcolemma is intimately involved in the extrusion of $\mathrm{Ca}^{2+}$ across the cell membrane [114], the inhibition of sarcolemmal $\mathrm{Ca}^{2+}$-pump ATPase by oxygen free radicals could lead to decrease $\mathrm{Ca}^{2+}$ extrusion from the cytosol, resulting in an increase in cytosolic $\mathrm{Ca}^{2+}$ concentration.

Mechanisms for the changes in heart sarcolemmal ion-transporting systems by oxygen free radicals

To investigate the role of sulfhydryl groups in causing depression of the sarcolemmal $\mathrm{Ca}^{2+}$-pump activities, we [115] examine the following aspects in heart sarcolemmal membranes:

1. the effects of sulfhydryl-reducing agents, such as DDT or cysteine on the depression of $\mathrm{Ca}^{2+}$-pump activities due to oxygen free radicals,

2. the effects of sulfhydryl groups reagents, such as Nethylmaleimide (NEM), on $\mathrm{Ca}^{2+}$-pumpATPase activity, and 
3. the effects of oxygen free radicals on sulfhydryl groups.

The inhibition of sarcolemmal $\mathrm{Ca}^{2+}$-pump activities by oxygen free radicals was prevented by the addition of DTT or cysteine in a dose-dependent manner [115]. NEM inhibited $\mathrm{Ca}^{2+}$-pump activity both in a dose- and a time-dependent manner [115]; DTT and cysteine prevented the changes in $\mathrm{Ca}^{2+}$-pump activity because of NEM [115]. Hearts sarcolemmal sulfhydryl groups were depressed by various types of oxygen free radical-generating systems both in a doseand a time-dependent manner; free radical scavengers showed protective effects on the sulfhydryl groups depression by oxygen free radicals [115]. Furthermore, there was a significant correlation between changes in sarcolemmal $\mathrm{Ca}^{2+}$-pump ATPase activity and sarcolemmal sulfhydryl groups [115]. These results indicate that oxygen free radicals depress the heart sarcolemmal $\mathrm{Ca}^{2+}$-pump activity by modifying the sulfhydryl groups in the sarcolemmal membrane. In addition, because sulfhydryl groups are known to regulated other membrane-bound ion-transporting systems such as $\mathrm{Na}^{+}-\mathrm{K}^{+}$ATPase, $\mathrm{Na}^{+}-\mathrm{Ca}^{2+}$ exchange, and voltagedependent $\mathrm{Ca}^{2+}$ channel of sarcolemma, $\mathrm{Ca}^{2+}$ release protein and $\mathrm{Ca}^{2+}$-pump ATPase of sarcoplasmic reticulum [84, 106, 116-128], it is likely that the oxidation of sulfhydryl groups in the membrane-bound ion-transporting systems may lead to depression of the activities due to oxygen free radicals.

Not only the direct reactions of oxygen free radicals with membrane-bound enzyme proteins but lipid peroxidation of membrane phospholipids by free radicals can affect the enzyme activities. Accumulation of hydroperoxides resulted from peroxidation of membrane phopholipids can inactivate the enzymes activities by modifying the lipid microenvironment, by oxidizing amino acid residues, or by mediating polypeptide chain polymerization reactions [31].

\section{III. $\mathrm{Ca}^{2+}$ translocating processes of sarcoplasmic reticulum}

Hess et al. [129-135] have studied the effects of various types of oxygen free radical-generating systems on $\mathrm{Ca}^{2+}$ transporting systems of cardiac sarcoplasmic reticulum. They observed that $\mathrm{Ca}^{2+}$-pump ATPase activity and steady-state $\mathrm{Ca}^{2+}$ uptake were depressed by free radicals [129-135]. Direct measurement of the number and turnover of the pump units indicated that the number of the units was unchanged but turnover rate was decreased by oxygen free radicals [131]. Furthermore, exposure to oxygen free radicals increased the passive permeability of the sarcoplasmic reticular vesicles to $\mathrm{Ca}^{2+}$, but the increased permeability per se was insufficient to explain the effects of oxygen free radicals on $\mathrm{Ca}^{2+}$ pump ATPase activity [131]. Cumming and Holmberg et al. $[136,137]$ have studied the effects of free radicals, which was produced by the illumination of rose bengal, on the sheep cardiac sarcoplasmic reticulum $\mathrm{Ca}^{2+}$ release channel which was inserted into synthetic lipid bilayers. They found that $\mathrm{Ca}^{2+}$ release channel open probability was increased initially, and that continued illumination resulted in an irreversible loss of channel function and subsequent bilayer disruption [136-138]. They also showed that ryanodine binding in isolated cardiac membranes was reduced by oxygen free radicals, with associated degradation of a $340 \mathrm{kD}$ protein, which is thought to be the ryanodine receptor and sarcoplasmic reticular $\mathrm{Ca}^{2+}$ release channel complex [136-138]. Abramson et al. [118, 119] and Zaidi et al. [126] reported that oxidizing agents were found to induce rapid $\mathrm{Ca}^{2+}$ efflux from actively loaded sarcoplasmic reticular vesicles isolated from rabbit skeletal muscle. These data indicate that when sarcoplasmic reticulum is exposed to oxygen free radicals, $\mathrm{Ca}^{2+}$ release from sarcoplasmic reticulum to cytosol is promoted and $\mathrm{Ca}^{2+}$ sequestration from cytosol into sarcoplasmic reticulum lumen is inhibited.

Scherer et al. [123] and other researchers [121, 122] suggested that decline in $\mathrm{Ca}^{2+}$-pump ATPase activity was due to oxidation of sulfhydryl groups as evidenced by the ability of sulhydryl groups reducing agents to prevent inhibition of the ATPase activity, the decline in sulfhydryl content of oxidized sarcoplasmic reticulum, and the ability of sulfhydryl groups binding agents to inhibit the $\mathrm{Ca}^{2+}$-pump ATPase activity. Salama's group showed that reactive disulfide compounds, which are known to specifically oxidize free $\mathrm{SH}$ sites via a thiol-disulfide exchange reaction, trigger $\mathrm{Ca}^{2+}$ release from sarcoplasmic reticular vesicles $[116-119,126]$. Furthermore, they reported that sulfhydryl groups reducing agents can reverse the effects of reactive disulfide compounds [126]. Thus, the modification of sulfhydryl groups is important mechanism by which oxygen free radicals affect on $\mathrm{Ca}^{2+}$-transporting systems in sarcoplasmic reticulum, as well as in sarcolemmal membrane.

\section{Effects of oxygen free radicals on intra- cellular $\mathrm{Ca}^{2+}$ concentration}

Electrophysiological studies have shown that the application of oxygen free radicals caused delayed after depolarization and aftercontraction, which indicate $\mathrm{Ca}^{2+}$ overload of the cell $[44,49]$. It is, however, important to measure intracellular $\mathrm{Ca}^{2+}$ concentration during the application of oxygen free radicals. The development of calcium-sensitive fluorescent dyes has provided a new technique to monitor the changes in $\mathrm{Ca}^{2+}$ during the contraction cycle and to measure intracellular $\mathrm{Ca}^{2+}$ concentration. Using this technique, the effects of oxygen free radicals on intracellular $\mathrm{Ca}^{2+}$ concentration have been studied [44, 139-142]. Hayashi et al. [44] reported that rod-shaped myocytes became shortened or rounded (contracture) after the application of 0.1 and $1 \mathrm{mM} \mathrm{H}_{2} \mathrm{O}_{2}$ in isolated guinea pig ventricular 
myocytes, and that intracellular $\mathrm{Ca}^{2+}$ concentration $\left(\left[\mathrm{Ca}^{2+}\right]\right.$;), measured by the fura- $2340 / 380$ ratio, increased from the control values of 53 and $68 \mathrm{nmol} / 1$ to 110 and $105 \mathrm{nmol} / 1$ when cells were shortened during the perfusion of 0.1 and $1 \mathrm{mM} \mathrm{H}_{2} \mathrm{O}_{2}$, respectively, Burton et al. [139] observed that exposure of cultured rat ventricular myocytes to free radical-generating solution $(2.3 \mathrm{mM}$ purine, $0.01 \mathrm{U} / \mathrm{ml}$ xanthine oxidase, and $2.4 \mu \mathrm{M}$ iron-loaded transferrin) altered $\left[\mathrm{Ca}^{2+}\right]_{i}$ : fura-2 fluorescence ratio which indicate $\left[\mathrm{Ca}^{2+}\right]_{\mathrm{i}}$ was $639 \%$ of the control value after approximately $30-70 \mathrm{~min}$ with cessation of normal $\mathrm{Ca}^{2+}$ transients. They also reported that there was no increase in $\left[\mathrm{Ca}^{2+}\right]_{i}$ when myocytes pretreated with $10 \mu \mathrm{M} \alpha$-tochopherol for 18-24 hr were exposed to free radicals [139]. Josephson et al. [140] reported that measurements in isolated rat ventricular myocytes loaded with indo1 demonstrated rises in both systolic and diastolic fluorescence ratio following exposure to the free radical-generating system (1-10 $\mathrm{mM} \mathrm{H}_{2} \mathrm{O}_{2}$ plus $\mathrm{Fe}^{3+}$-nitrilotriacetate): the $\mathrm{Ca}^{2+}$ overload was prevented by the $\mathrm{Ca}^{2+}$ channel antagonist, nitrendipine, suggesting that the $\mathrm{Ca}^{2+}$ overload occured largely due to $\mathrm{Ca}^{2+}$ influx through voltage gated $\mathrm{Ca}^{2+}$ channels. Liu et al. [141] reported that the effect of oxidized low density lipoprotein (LDL) on the $\mathrm{Ca}^{2+}$ transients of isolated rabbit cardiomyocytes using fura- 2 technique. They observed that the systolic $\mathrm{Ca}^{2+}$ concentration in transients was significantly increased after treatment with $100 \mu \mathrm{g}$ of oxidized LDL cholesterol/ml for $16 \mathrm{~min}$ without any effect on the diastolic $\mathrm{Ca}^{2+}$ concentration [141]. Eley et al. [142] showed exciting data concerning the effect of oxygen free radicals on $\mathrm{Ca}^{2+}$ homeostasis in isolated rabbit ventricular myocytes which were loaded with fura-2 and superfused with $100 \mu \mathrm{m} \mathrm{HOCl}$ under voltage-clamped conditions. In these experiments, they observed that the amplitude of the $\mathrm{Ca}^{2+}$ transients was reduced from $402 \mathrm{nM}$ to $82 \mathrm{nM}$ while $\left[\mathrm{Ca}^{2+}\right]_{\mathrm{i}}$ increased from $78 \mathrm{nM}$ to $265 \mathrm{nM}$ within 200 seconds after $\mathrm{HOCl}$ addition: during this time, the amplitude of the slow inward currents increased by $10 \%$. This sustained steady-state rise in $\left[\mathrm{Ca}^{2+}\right]_{i}$ occured even in the absence of extracellular $\mathrm{Ca}^{2+}$ but was virtually abolished by preexposure to $10 \mathrm{mM}$ caffeine [142] Furthermore, although washout of HOC1 failed to induce recovery, subsequent exposure to the dithiol reducing agent dithiothreitol caused a rapid restoration of both the steadystate $\left[\mathrm{Ca}^{2+}\right]_{i}$ and $\mathrm{Ca}^{2+}$ transient amplitude. Therefore, they concluded that $\mathrm{HOCl}$ caused a rise of $\left[\mathrm{Ca}^{2+}\right]_{i}$ by inducing the release of $\mathrm{Ca}^{2+}$ from internal stores and by impairing cellular extrusion mechanisms, and that these effects occur through alteration of protein thiol redox status [142].

\section{References}

1. Arroyo CM, Kramer JH, Dickens BF, Weglicki WB: Identification of free radicals in myocardial ischemia/reperfusion by spin trapping with nitrone DMPO. FEBS Lett 221: 101-104, 1987

2. Bolli R, Patel BS, Jeroudi MO, Lai EK, McCay PB: Demonstration of free radical generation in "stunned" myocardium of intact dogs with the use of the spin trap alpha-phenyl $\mathrm{N}$-tert-butyl nitrone. J Clin Invest 82: $476-485,1988$

3. Garlick PB, Davies MJ, Hearse DJ, Slater TF: Direct detection of free radicals in the reperfused rat heart using electron spin resonance spectroscopy. Circ Res 61: 757-760, 1987

4. Zweier JL, Flaherty JT, Weisfeldt ML: Direct measurement of free radical generation following reperfusion of ischemic myocardium. Pro Natl Sci USA 84: 1404-1407, 1987

5. Gupta $M$, Singal PK: Oxygen radical injury in the presence of desferal, a specific iron-chelating agent. Biochem Pharmacol 36: 3774-3777, 1987

6. Przyklenk K, Whittaker P, Kloner RA: Direct evidence that oxygen free radicals cause contractile dysfunction in vitro. Circulation 78 (Suppl II): II-264, 1988

7. Przyklenk K., Kloner RA: Superoxide dismutase plus catalase improve contractile function in the canine model of the "stunned myocardium". Circ Res 58: 148-156, 1986

8. Bolli R, Zhu WX, Hartley CJ, Michael LH, Repine JE, Hess ML, Kukreja RC, Robert R: Attenuation of dysfunction in the postischemic "stunned" myocardium by dimethylthiourea. Circulation 76: 458-468, 1987

9. Charlat ML, O'Neill PG, Egan JM, Abernethy DR, Michael LH, Myers $\mathrm{LH}$, Robert R, Bolli R: Evidence for a pathogenetic role of xanthine oxidase in the "stunned" myocardium. Am J Physiol 252: H566-H577, 1987

10. Bolli R, Jeroudi MO, Pater BS, Arouma OI, Halliwell B, Lai EK, McCay PB: Marked reduction of free radical generation and contractile dysfunction by antioxidant therapy begun at the time of reperfusion. Circ Res 65 : $607-615,1989$

11. KatzAM, Reuter H: Cellular calcium and cardiac cell death. Am J Cardiol 44: 188-190, 1979

12. Nayler WG: The role of calcium in the ischemic myocardium. Am J Pathol 102: 262-270, 1981

13. Lee HC, Mohabir R, Smith N, Franz MR, Clusin WT: Effect of ischemia on calcium-dependent fluorescence transients in rabbit hearts containing indo-1. Circulation 78: 1047-1059, 1988

14. Lee HC, Smith N, Mohabir R, Clusin WT: Cytosolic calcium transients from the beating mammalian heart. Proc Natl Acad Sci USA 252: C441-C449, 1987

15. Marban E, Kitakaze M, Koretsune Y, Yue DT, Chacko VP, Pike MM: Quantification of $\left[\mathrm{Ca}^{2+}\right]_{i}$ in perfused heart: Critical evaluation of the $5 \mathrm{~F}$ BAPTAand nuclear magnetic resonance method as applied to the study of ischemia and reperfusion. Circ Res 66: 1255-1267, 1990

16. Steenbergen C, Murphy E, Levy L, London RE: Elevation in cytosolic free calcium concentration early in myocardial ischemia in perfused rat heart. Circ Res 60: 700-707, 1987

17. Farber JL, Chien KR, Mittnacht S: The pathogenesis of irreversible cell injury in ischemia. Am J Pathol 102: 271-281, 1981

18. Tsokos J, Bloom S: Effects of calcium on respiration and ATP contect of isolated, leaky, heart muscle cells. J Mol Cell Cardiol 9: 823-836, 1977

19. Fabiato A, Fabiato $\mathrm{F}$ : Calcium-induced release of calcium from the sarcoplasmic reticulum of skinned cells from adult human, dog, cat, rabbit, rat, 
and frog hearts and from fetal and new-born rat ventricles. Ann NY Acad Sci 307: 491-522, 1978

20. Fabiato A: Calcium-induced release of calcium from the cardiac sarcoplasmic reticulum. Am J Physiol 245: C1-C14, 1983

21. Langer GA, Frank JS, Philipson KD: Ultrastructure and calcium exchange of the sarcolemma, sarcoplasmic reticulum and mitochondria of the myocardium. Pharmacol Ther 16: 331-376, 1982

22. Mullins LJ: The generation of electric currents in cardiac fibers by $\mathrm{Na} / \mathrm{Ca}$ exchange. Am J Physiol 236: C103-C110, 1979

23. Philipson KD, Ward $\mathrm{R}: \mathrm{Ca}^{2+}$ transport capacity of sarcolemmal $\mathrm{Na}^{+}-\mathrm{Ca}^{2+}$ exchange. Extrapolation of vesicle data to in vivo conditions. J Mol Cell Cardiol 18: 943-951, 1986

24. Bers DM, Langer GA: Uncoupling cation effects on cardiac contractility and sarcolemmal Ca binding. Am J Physiol 237: H332-H341, 1979

25. Bers DM, Philipson KD, Langer GA: Cardiac contractility and sarcolemmal calcium binding in several cardiac preparation. Am J Physio 240: H576-H583, 1981

26. Langer GA: Calcium at the Sarcolemma: Its Role in Control of Myocardial Contraction. In: R.D. Nathan (ed). Cardiac muscle: The regulation of excitation and contraction. Academic Press, Orlando, 1986, pp 269-281

27. Dhalla NS, Pierce GB, Panagia V, Singal PK, Beamish RE: Calcium movements in relation to heart function. Basic Res Cardiol 77: 117-139, 1982

28. Dhalla NS, Smith CI, Pierce GN, Elimban V, Makino N, Khatter JC: Heart sarcolemmal cation pumps and binding sites. In: H. Rupp (ed). Regulation of heart function. Thiame-Stratton, New York, 1986, pp 126-136

29. Kaneko M, Singal PK, Dhalla NS: Alterations in heart sarcolemmal $\mathrm{Ca}^{2+}$ ATPase and $\mathrm{Ca}^{2+}$-binding activities due to oxygen free radicals. Basic Res Cardiol 85: 45-54, 1990

30. Philipson KD, Bers DM, Nishimoto AY: The role of phospholipids in the $\mathrm{Ca}^{2+}$ binding of isolated sarcolemma. J Mol Cell Cardiol 12: 1159-1173, 1980

31. Freeman BA, Crapo JD: Biology of Disease; free radicals and tissue injury. Lab Invest 47: 412-426, 1982

32. Bean BP: Classes of calcium channels in vertebrate cells. Annu Rev Physiol 51: 367-384, 1989

33. Pelzer D, Pelzer S, McDonald TF: Properties and regulation of calcium channels in muscle cells. Rev Physiol Biochem Pharmacol 114: 108-207, 1990

34. Porzig H: Pharmacological modulation of voltage-dependent Ca channels in intact cells. Rev Physiol Biochem Pharmacol 114: 209-262, 1990

35. Carmeliet E, Vereecke J: Electrogenesis of the action potential and automaticity. In: Handbook of Physiology, vol I, The Heart; Section 2: The Cardiovascular System, American Physiological Society, Bethesda, Maryland, 1979, pp 269-334

36. Dorr Th, Denger R, Dorr A, Trautwein W: Ionic currents contributing to the action potential in single ventricular myocytes of the guinea pig studied with action potential clamp. Pflugers Arch 416:230-237, 1990

37. Noble D: The surprising heart: A review of recent progress in cardiac electrophysiology. J Physiol (Lond) 353: 1-50, 1984

38. Gibbons WR, Fozzard HA: Relationships between voltage and tension in sheep cardiac Purkinje fibers. J Gen Physiol 65: 345-365, 1975

39. Nabeuer M, Callewaert G, Cleemann L, Morad M: Regulation of calcium release is gated by calcium current, not gating charge, in cardiac myocytes. Science 244: 800-803, 1989

40. Tanabe T, Mikami A, Numa S, Beam KG: Cardiac-type excitation coupling in dysgenic skeletal muscle injected with cardiac dihydropyridine receptor cDNA. Nature 344: 451-453, 1990

41. Trautwein W, McDonald TF, Tripathi $O$ : Calcium condactance and tension in mammalian ventricular muscle. Pflugers Arch 354: 55-74, 1975

42. Kaneko M, Lee SL, Wolf CM, Dhalla NS: Reduction of calcium channel antagonist binding sites by oxygen free radicals in rat heart. $\mathrm{J} \mathrm{Mol}$ Cell Cardiol 21: 935-943, 1989

43. Barrington PL, Meier Jr CF, Weglicki WB: Effects of free radicals on the canine myocyte action potential. Fed Proc 44: 1578, 1986

44. Hayashi H, Miyata H, Watanabe $H$, Kobayashi A, Yamazaki N: Effects of hydrogen peroxide on action potentials and intracellular $\mathrm{Ca}^{2+}$ concentration of guinea pig heart. Cardiovasc Res 23: 767-773, 1989

45. Beresewisz A, Horackova M: Alterations in electrical and contractile behavior of isolated cardiomyocytes by hydrogen peroxide: Possible ionic mechanisms. J Mol Cell Cardiol 23: 899-918, 1991

46. Jabr RI, Cole WC: Alterations in electrical activity and membrane currents induced by intracellular oxygen-derived free radical stress in guinea pig ventricular myocytes. Circ Res 72: 1229-1244, 1993

47. Pailandi RT, Perry MA, Campbell TJ: Proarrhythmic effects of an oxygenderived free radical generating system on action potentials recorded from guinea pig ventricular myocardium: A possible cause of reperfusion-induced arrhythmias. Circ Res 61: 50-54, 1987

48. Cerbai E, Ambrosio G, Porciatti F, Chiariello M, Giotti A, Mugelli A: Cellular electrophysiological basis for oxygen radical-induced arrhythmias: A path-clamp study in guinea pig ventricular myocytes. Circulation 84 : 1773-1782, 1991

49. Nakaya $\mathrm{H}$, Tohse $\mathrm{N}$, Kanno M: Electrophysiological derangements induced by lipid peroxidation in cardiac tissue. Am J Physiol 253: H1089-H1097, 1987

50. Goldhaber JI, Ji S, Lamp ST, Weiss JN: Effects of exogenous free radicals on electromechanical function and metabolism in isolated rabbit and guinea pig ventricle: Implication for ischemia and reperfusion injury. J Clin Invest 83 : $1800-1809,1989$

51. Tarr M, Valenzeno DP: Modification of cardiac ionic currents by photosensitizer-generated reactive oxygen. J Mol Cell Cardiol 23: 639-649, 1991

52. Nakaya H, Takeda Y, Tohse N, Kamo M: Mechanism of the membrane depolarization induced by oxidative stress in guinea-pig ventricular cells. J Mol Cell Cardiol 24: 523-534, 1992

53. Levitzki A: $\beta$-Adrenergic receptors and their mode of coupling to adenylate cyclase. Physiol Rev 66: 819-854, 1986

54. Gilman AG: G protein transducer of receptor generated signals. Annu Rev Biochem 56: 615-649, 1987

55. Ikegaya T, Kobayashi A, Hong RB, Masuda H, Kaneko M, Yamazaki N: Stimulatory guanine nucleotide-binding protein and adenylate cyclase activities in Bio 14.6 cardiomyopathic hamsters at the hypertrophic stage. Mol Cell Biochem 110: 83-90, 1992

56. Robishow JD, Foster KA: Role of $G$ proteins in the regulation of the cardiovascular system. Annu Rev Physiol 51: 229-244, 1989

57. Mattera R, Graziano MP, Yatani A, Zhou Z, Graf R, Codina J, Birnbaumer L, Gilman AG, Brown AM: Splice variants of the $\alpha$ subunit of the G protein $\mathrm{G}_{\mathrm{s}}$ activate both adenylyl cyclase and calcium channels. Science 243: 804-806, 1989

58. Yatani A, BrownAM: Rapid $\beta$-adrenergic modulation of cardjac calcium channel currents by a fast $G$ protein pathway. Science 245: 71-74, 1989

59. Karozewski P, Bartel S, Krause EG; Differential sensitivity to isoprenaline of troponin I and phospholamban phosphorylation in isolated rat hearts. Biochem J 266: 115-122, 1990

60. Haenen G, Dansik PV, Vermeulen NPE, Timmerman H, Bast A: The effect of hydrogen peroxide on $\beta$-adrenoceptor function in the heart. Free Radic Res Commun 4: 243-249, 1988

61. Kaneko M, Chapman DC, Ganguly PK, Beamish RE, Dhalla NS: Modification of cardiac adrenergic receptors by oxygen free radicals. Am J Physiol 260 (Heart Circ Physiol 29): H821-H826, 1991

62. Masuda H, Kaneko M, Hong RB, Ikegaya T, Hayashi $H$, Kobayashi A, Yamazaki N: Effects of hydrogen peroxide on stimulatory guanine nucleotide-binding protein in rat heart. Jpn Circ J 1993, in press

63. Will-Shahab L, Schimke I, Haberland A, Kotner I: Responsiveness of cardiac adenylate cyclase in the normal and ischemic myocardium. Role of oxygen free radicais. Biomed Biochim Acta 46: 427-432, 1987

64. Shimke I, Haberland A, Will-Shahab L, Kuttner I, Paies B; Free radical 
induced damage of cardiac sarcolemma (SL) and activity loss of breceptor adenylate cyclase system (b-RAS). A comparison of the time course. Biomed Biochim Acta 48: 69-72, 1989

65. Langer GA: Sodium-calcium exchange in the heart. Annu Rev Physiol 44: $435-449,1982$

66. Blaustein MP: Sodium/calcium exchange and the control of contractility in cardiac muscle and vascular smooth muscle. J Cardiovasc Pharmacol 12 (suppl 5): 536-568, 1988

67. Deitmer JW, Ellis D: The intracellular sodium activity of cardiac Purkinje fibres during inhibition and re-activation of the Na-K pump. J Physiol 284: 241-259, 1978

68. Deitmer JW, Ellis D: Changes in the intracellular sodium activity of sheep heart Purkinje fibres produced by calcium and other divalent cations. J Physiol (Lond) 277: 437-453, 1978

69. Vaughan-Jones RD, Lederer W, Eisner Da: $\mathrm{Ca}^{2+}$ ions can affect intracellular pH in mammalian cardiac muscle. Nature 301: $522-524,1983$

70. Kim D, Cragoe EJ, Smith TW: Relationships among sidium pump inhibition, sodium-calcium exchange, and sodium-hydrogen exchange activities and calcium-hydrogen interaction in cultured chick heart cells. Circ Res 60: 185-193, 1987

71. Kim D, Smith TW: Cellular mechanisms underlying calcium-proton interaction in cultured chick ventricular cells. J Physiol (Lond) 398 $391-340,1988$

72. Kim D, Smith TW: Effect of amiloride and ouabain on contractile state, $\mathrm{Ca}$ fluxes and cellular Na content in cultured chick heart cells. Mol Pharmacol 29: 363-371, 1986

73. Frelin $\mathrm{C}$, Vigne $\mathrm{P}$, Lazdunski $\mathrm{M}$ : The role of the $\mathrm{Na}^{+} / \mathrm{H}^{+}$exchange system in cardiac cells in relation to the control of the internal $\mathrm{Na}^{+}$concentration. J Biol Chem 259: 8880-8885, 1984

74. Satoh H, Hayashi H, Kobayashi A, Yamashita Y, Yamazaki N: Regulation of $\left[\mathrm{Na}^{+}\right]_{\mathrm{i}}$ and $\left[\mathrm{Ca}^{2+}\right]_{\mathrm{i}}$ in guinea pig myocytes - study by fluorescent indicators SBFI and FLUO-3-. Am J Physiol 1994, in press

75. Kramer JH, Mak IT, Weglicki WB: Differential sensitivity of canine cardiac sarcolemmal and microsomal enzymes to inhibition by free radicalinduced lipid peroxidation. Circ Res 55: 120-124, 1984

76. Kim MS, Akera T: $O$, free radicals: Cause of ischemia-reperfusion injury to cardiac $\mathrm{Na}^{+}-\mathrm{K}^{4}$-ATPase. Am J Physiol 252: $\mathrm{H} 252-\mathrm{H} 257,1987$

77. Bhatnagar A, Srivastava SK, Szabo G: Oxidative stress alters specific membrane currents in isolated cardiac myocytes. Circ Res 67: $535-549$, 1990

78. Kukreja RC, Weaver AB, Hess ML: Sarcolemmal sodium-potassiumATPase: Inactivation by neutrophil-derived free radicals and oxidants. Am J Physiol 259: H1330-H1336, 1990

79. Fong KL, McCay PB, Poyer JL: Evidence that peroxidation of lysosomal membranes is initiated by hydroxyl free radicals produced during flavin enzyme activity. J Biol Chem 248: 7792-7797, 1973

80. Player TJ, Hulton HO: The effect of lipid peroxidation on the calciumaccumulating ability of the microsomal fraction isolated from chicken breast muscle. Biochem J 174: 17-22, 1978

81. Hicks M, Gebicki JM: A quantitative relationship between permeability and the degree of peroxidation in ufasome membranes. Biochern Biophys Res Comm 80: 704-708, 1978

82. Ytrehus M, Myklebust R, Olsen R, Mjes OD: Ultrastructural changes induced in the isolated rat heart by enzymatically generated oxygen radicals. J Mol Cell Cardiol 19: 379-389, 1987

83. LebedevAV, Levitsky DO, Loginov VA, Smimov VN: The effect of primary products of lipid peroxidation on the transmembrane transport of calcium ions. J Mol Cell Cardiol I4 (suppl 3): 99-103, 1982

84. Hata T, Kaneko M, Beamish RE, Dhalla NS: Influence of oxygen free radicals on heart sarcolemmal $\mathrm{Na}^{+}-\mathrm{Ca}^{2+}$ exchange. Coron Art Dis 2: $397-407,1991$

85. Barrow DA, Lentz BR: A model for the effect of lipid oxidation on diphenylhexatriene fluorescence in phospholipid vesicles. Biochim
Biophys Acta 645: 17-23, 1981

86. Rice-Evans C, Hochstein P: Alterations in erythrocyte membrane fluidity by phenylhydrazine-induced peroxidation of lipids. Biochem Biophys Res Comm 100: 1537-1542, 1981

87. Eichenberger K, Bohni P, Winterhalter KH, Kawato S, Richter C: Microsomal lipid peroxidation causes an increase in the order of the membrane lipid domain. FEBS Lett 142: 59-62, 1982

88. Bruch RC, Thayter WS: Differential effect of lipid peroxidation on membrane fluidity as determined by electron spin resonance probes. Biochim Biophys Acta 733: 216-222, 1983

89. Niki E, Komuro E, Takahashi M, Urano S, Ito E, Terao K: Oxidative hemolysis of erythrocytes and its inhibition by free radical scavengers. J Biol Chem 263: 19809-19814, 1988

90. Vladimirov VA, Olenev VI, Suslova TB, Cheremisina ZP: Lipid peroxidation in mitochondrial membrane. In: R. Paoletti and D. Kritchevsky (eds).Advances in lipid research.Academic Press, NewYork, 1980, 17: pp 173-249

91. Watanabe H, Kobayashi A, Yamamoto T, Suzuki S, Hayashi H, Yamazaki $\mathrm{N}$ : Alterations of human erythrocyte membrane fluidity by oxygen-derived free radicals and calcium. Free Rad Biol Med 9: 507-514, 1990

92. Grzelinska E, Bartasz G, Gwozdzinski K, Leyko W: A spin-label study of the effect of gamma radiation on erythrocyte membrane. Influence of lipid peroxidation on membrane structure. Int J Radiat Biol 36: 325-334, 1979

93. Kaneko M, Yuan GX, Suzuki H, Matsumoto Y, Kobayashi A, Yamazaki $\mathrm{N}$ : Susceptibility of cardiac membranes to oxygen free radjcals. J Mol Cell Cardiol 25 (suppl II): S 21, 1993

94. Bremer J, Greenberg DM: Methyl transfering enzyme system of microsomes in the biosynthesis of lecithin (phosphatidylcholine). Biochim Biophys Acta 46: 205-216, 1961

95. Hirata F, Axelrod J: Enzymatic methylation of phosphatidylethanolamine increases erythrocyte membrane fluidity. Nature 275: 219-220, 1978

96. Mato JM, Alemany S: What is the function of phospholipid N-methylation? Biochem J 213: 1-10, 1983

97. Ganguly PK, Panagia V, Okumura K, Dhalla NS: Activation of $\mathrm{Ca}^{2+}$ stimulatedATPase by phospholipid $\mathrm{N}$-methylation in cardiac sarcoplasmic reticulum. Biochem Biophys Res Comm 130: 472-478, 1985

98. Panagia V, Okumura K, Makino N, Dhalla NS: Stimulation of $\mathrm{Ca}^{2+}$ pump in rat heart sarcolemma by phosphatidylethanolamine $\mathrm{N}$-methylation. Biochim Biophys Acta 856: 383-387, 1986

99. Panagia V, Makino N, Ganguly PK, Dhalla NS: Inhibition of $\mathrm{Na}^{+}-\mathrm{Ca}^{2+}$ exchange in heart sarcolemmal vesicles by phosphatidylethanolamine $\mathrm{N}$ methylation. Eur J Biochem 166: 597-603, 1987

100. Strittmatter WJ, Hirata F, Axelrod J: Phospholipid methylation unmasks cryptic b-adrenergic receptors in rat reticulocytes. Science 204 1205-1207, 1979

101. Kaneko M, Panagia V, Paolillo G, Majumder S, Ou C, Dhalla NS: Inhibition of cardiac phosphatidylethanolamine $\mathrm{N}$-methylation by oxygen free radicals. Biochim Biophys Acta 1021: 33-38, 1990

102. Xie Z, Wang Y, Askari A, Huang WH, Klaunig JK, AskariA: Studies on the specificity of the effects of oxygen metabolites on cardiac sodium pump. J Mol Cell Cardiol 22: 911-920, 1990

103. Trumble WR, Sutko JL, Reeves JP:ATP-dependent calcium transport in cardiac sarcolemmal membrane vesicles. Life Sci 27: 207-214, 1980

104. Caroni $\mathrm{P}$, Carafoli $\mathrm{E}$ : The $\mathrm{Ca}^{2+}$-pumping ATPase of heart sarcolemma. $\mathrm{J}$ Biol Chem 256: 3263-3270, 1981

105. Caroni P, Zurini M, Clark A: Transport ATPases. NY Acad Sci, New York 1982, pp 403-420

106. Reeves JP, Bailey CA, Hale CC: Redox modification of sodium-calcium exchange activity in cardiac sarcolemmal vesicles. $J$ Biol Chem 261: 4948-4955, 1986

107. Shi ZQ, Davison AJ, Tibbits GF: Effects of active oxygen generated by $\mathrm{DTT} / \mathrm{Fe}^{2+}$ on cardiac $\mathrm{Na}^{+}-\mathrm{Ca}^{2+}$ exchange and membrane perme- 
ability to $\mathrm{Ca}^{2+}$. J Mol Cell Cardiol 21: 1009-1016, 1989

108. Kutryk MJB, Pierce GN: Stimulation of sodium-calcium exchange by cholesterol incorporation into isolated cardiac sarcolemmal vesicles. J Biol Chem 263: 13167-13172, 1988

109. Daly MJ, Elz IS, Nayler WG: Sarcolemmal enzymes and $\mathrm{Na}^{+}-\mathrm{Ca}^{2+}$ exchange in hypoxic, ischemic and reperfused rat hearts. Am J Physiol 247: $\mathrm{H} 237-\mathrm{H} 243,1984$

110. Meno H, Jarmakani JM, Philipson KD: Effect of ischemia on sarcolemmal $\mathrm{Na}^{+}-\mathrm{Ca}^{2+}$ exchange in neonatal hearts. Am $\mathrm{J}$ Physiol 256: $\mathrm{H} 1615-\mathrm{H} 1620,1989$

111. Dixon IMC, Eyolfson DA, Dhalla NS: Sarcolemmal $\mathrm{Na}^{+}-\mathrm{Ca}^{2+}$ exchange activity in hearts subjected to hypoxia reoxygenation. Am J Physiol 253: H1026-H1034, 1987

112. Bersohn MM, Philipson KD, Fukushima JY: Sodium-calcium exchange and sarcolemmal enzymes in ischemic rabbit hearts. Am J Physiol 242: C288-C292, 1982

113. Dixon IMC, Kaneko M, Hata T, Panagia V, Dhalla NS: Alterations in cardiac membrane $\mathrm{Ca}^{2+}$ transport during oxidative stress. Mol Cell Cardiol 99: 125-133, 1990

114. Kaneko M, Beamish RE, Dhalla NS: Depression of heart sarcolemmal $\mathrm{Ca}^{2+}$-pump activity by oxygen free radicals. Am $\mathrm{J}$ Physiol 256: H368-H374, 1989

115. Kaneko M, Elimban V, Dhalla NS: Mechanism for depression of heart sarcolemmal $\mathrm{Ca}^{2+}$ pump by oxygen free radicals. Am J Physiol 257: H804-H811, 1989

116. Salama G, Zaidi NF, Abramson JJ: Reactive disulfide compounds trigger $\mathrm{Ca}^{2+}$ release from sarcoplasmic reticulum (SR) vesicles. Biophys $\mathrm{J}$ 53: 420,1988

117. Abramson JJ, Salama G: Critical sulfhydryls regulate calcium release from sarcoplasmic reticulum. J Bioenergetics Biomemb 21: 283-294, 1989

118. Abramson JJ, Cronin JR, Salama G: Oxidation induced by phthalocyanine dyes causes rapid calcium release from sarcoplasmic reticulum vesicles. Arch Biochem Biophys 263: 245-255, 1988

119. Abramson JJ, Buck E, Salama G, Casida JE, Pessah IN: Mechanism of anthraquinone-induced calcium release from skeletal muscle sarcoplasmic reticulum. J Biol Chem 263: 18750-18758, 1988

120. Zaidi NF, Langenaur CF: Disulfide linkage of biotin identifies a 106$\mathrm{kDa} \mathrm{Ca}{ }^{2+}$ release channel in sarcoplasmic reticulum. J Biol Chem 264: 21737-21747, 1989

121. Yamada S, Ikemoto N: Distinction of thiols involved in the specific reaction steps of the $\mathrm{Ca}^{2+}$-ATPase of the sarcoplasmic reticulum. J Biol Chem 253: $6801-6807,1978$

122. Yoshida $\mathrm{H}$, Tonomura Y: Chemical modification of the $\mathrm{Ca}^{2+}$-dependent ATPase of sarcoplasmic reticulum from skeletal muscle. I. Binding of Nethylmaleimide to sarcoplasmic reticulum: Evidence for sulfhydryl groups in the active site of ATPase and for conformation changes induced by adenosine tri-and diphosphate. J Biochem 79: 649-654, 1976

123. Scherer NM, Deamer DW: Oxidative stress impairs the function of sarcoplasmic reticulum by oxidation of sulfhydryl groups in the $\mathrm{Ca}^{2+}$-ATPase. Arch Biochem Biophys 246: 589-601, 1986

124. Steinberg H, Greenwald, RA, Moak SA, Das DK: The effect of oxygen adaptation on oxyradical injury to pulmonary endothelium. Am Rev Respir Dis 128: 94-97,1983

125. Pierce GN, Ward R, Philipson KD: Role for sulfur containing groups in the sodium-calcium exchange of cardiac sarcolemmal vesicles. Memb Biol 94: 217-225, 1986
126. Zaidi NF, Lagenaur CF, Abrahamson JJ: Reactive disulfides trigger $\mathrm{Ca}^{2+}$ releason from sarcoplasmic reticulum via an oxidation reaction. J Biol Chem 264: 21725-21736, 1989

127. Garcia ML, King VF, Siegel PKS, Reuben JP, Kagzorowski GJ; Binding of $\mathrm{Ca}^{2+}$ entry blockers to cardiac sarcolemmal membrane vesicles. J Biol Chem 261: 8146-8157, 1986

128. Grossmann H, Ferry DR, Goll A, Rombusch M: Molecular pharmacology of the calcium channel: evidence for subtypes, multiple drug-receptor sites, channel subunits, and the development of a radioiodinated 1,4dihydropyridine calcium channel label, $\left[{ }^{125} \mathrm{I}\right]$ iodipine. J Cardiovasc Pharmacol 6 (suppl 4): 608-621, 1984

129. Hess ML, Okabe E, Kontos HA: Proton and free oxygen radical interaction with the calcium transport system of cardiac sarcoplasmic reticulum. J Mol Cell Cardiol 13: 767-772, 1981

130. Hess ML, Krause S, Kontos HA: Mediation of sarcoplasmic reticulum disruption in the ischemic myocardium: Proposed mechanism by the interaction of hydrogen ions and oxygen free radicals. Adv Exp Biol Med 161: $377-387,1983$

131. Okabe E, Hess ML, Oyama M, Ito H: Characterization of free radical mediated damage of canine sarcoplasmic reticulum. Arch Biochem Biophys 225: 164-177, 1983

132. Hess ML, Okabe E,Ash P: Free radical mediation of the effects of acidosis on calcium transport by cardiac sarcoplasmic reticulum in whole heart homogenates. Cardiovasc Res 18: 149-157, 1984

133. Kukreja RC, Okabe E, Schrier G, Hess ML: Oxygen radical-mediated lipid peroxidation and inhibition of calcium ATPase activity of cardiac sarcoplasmic reticulum. Arch Biochem Biophs 261: 447-475, 1988

134. Okabe E, Odajima C, Taga R, Kukreja RC, Hess ML, Ito H: The effect of oxygen free radicals on calcium loading at steady state in canine sarcoplasmic reticulum. Mol Pharmacol 34: 388 394, 1988

135. Kukreja RC, WeaverAB, Hess ML: Stimulated human neutrophils damage cardiac sarcoplasmic reticulum function by generation of oxidants. Biochim Biophys Acta 990: 198-205, 1989

136. Cumming DVE, Holmberg SRM, Kusama Y, Shattock M, Williams A: Effects of reactive oxygen species on the structure and function of the calcium-release channel isolated from sheep cardiac sarcoplasmic reticulum. J Physiol 420: 88P, 1990

137. Holmberg SRM, Cumming DVE, Kusama Y: Reactive oxygen species modify the structure and function of the cardiac sarcoplasmic reticulum calcium-release channel. Cardioscience 2: 19-25, 1991

138. Shttock MJ, Hearse DH, Matuura H: lonic currents underlying oxidant stress-induced arrhythmias. In: J. Vereecke, P.P. Van Bogaert and F. Verdonk (eds). Ionic currents and ischemia. Leuven University Press, Leuven, 1990, pp 165-189

139. Burton KP, Morris AC, Massey KD, Buja M, Hagler HK: Free radicals alter ionic calcium levels and membrane phospholipids in cultured rat ventricular myocytes. J Mol Cell Cardiol 22: 1035-1047, 1990

140. Josephson RA, Silverman HS, Lakatta EG, Stern MD, Zweier JL: Study of the mechanisms of hydrogen peroxide and hydroxyl free radical-induced cellular injury and calcium overload in cardiac myocytes. J Biol Chem 266: 2354-2361, 1991

141. Liu K, Massaeli H, Pierce GN: The action of oxidized low density lipoprotein on calcium transients in isolated rabbit cardiomyocytes. J Biol Chem 268: 4145-4151, 1993

142. Eley DW, Korecky B, Fliss H, Desilets M: Calcium homeostasis in rabbit ventricular myocytes. Disruption by hydrochlorous acid and restoration by dithiothreitol. Circ Res 69: 1132-1138, 1991 